\title{
The Sea Is My Country: The Maritime World of the Makahs. Joshua L. Reid. 2015. Yale University Press, New Haven, CT. 400 pp.
}

\author{
Jill F. Mackin ${ }^{1 *}$ \\ ${ }^{1}$ Department of History and Philosophy, Montana State University, Bozeman, MT, USA. \\ *jill.mackin@montana.edu
}

Received August 4, 2017

OPENӘACCESS

Accepted August 24, 2017

DOI 10.14237/ebl.8.1.2017.1075

Copyright (c) 2017 by the author(s) licensee Society of Ethnobiology. This is an open-access article distributed under the terms of the Creative Commons Attribution-NonCommercial 4.0 International Public License (https://creativecommons.org/licenses/by-nc/4.0), which permits non-commercial use, distribution, and reproduction in any medium, provided the original author and source are credited.

In The Sea is My Country: The Maritime World of the Makahs, Joshua Reid presses back against myths of indigenous history and firmly scribes the name of the Makahs on the map. With an unrelenting pursuit through two centuries of history, Reid holds tightly to the thread of Native resistance as it slowly unravels and then strengthens again. Concerned with the balance of power between settlers and Natives, Reid explores consecutive eras of colonial interaction including the fur trade, the solidification of borders and nation state infrastructures, and marine resource extraction. All the while, Reid reaches deep into the sources of historical understanding to balance the written record with scholarly evidence for Native motivations, such as cultural norms and existing intertribal relationships. Importantly to the field of ethnobiology, he arrives at a view of the deep connection the Makah had to the sea, their country, and how-embedded in a web of marine and terrestrial relationships - the Makah maintained their power and livelihood.

The first myth that Reid contends with is that of the blank map. He builds a view of the complexity of native borderlands and webs of intertribal power and control that existed before the arrival of non-Natives. Reid is curious about what comprises "tribal space." He concludes that it is a mix of native inertia, attributes of place, and the larger web of relationshuman and non. Tribal space also becomes a marine space through time, with an imaginary boundary line of emerging nation states running through it. Exploring indigenous borderlands as well as settlercolonial borderlands, Reid dispels the myth that settler-colonialism was a cut-and-paste arrangement in which a new political and economic system was imposed on a blank space and a simple society. Instead, settler-colonial structures were grafted onto an already existing political and economic structure, an indigenous trade network of varied peoples with historical relationships, diplomatic customs, and, sometimes, volatile power dynamics. Building on the borderlands scholarship of Adelman and Aron, Anzaldúa, and Truett, Reid clearly delineates the remnant layers in borderlands power structures.

Reid goes on to demonstrate how indigenous agency persists through this hybrid structure up to a tipping point in 1850 , when a series of compounding events-multiple diseases, loss of key Native leaders, increased numbers of settlers, and solidifying borders both geographic and political-began to erode native power. In Reid's telling, the Makahs are not victims whose static culture has disappeared. They have adapted new technologies and opportunities on their own terms. Carrying the story into the current era, Reid illustrates Makah adaptation to colonial legal and economic structures as they both fight to recover their traditional whale harvesting rights and engage in the marine extraction industry on their own terms while maintaining their position of power. Reid states, "By mixing their labor with the ocean through customary marine practices, Makahs transformed the sea into their country" (147). This pattern happens time and time again in which "holding their ground" is a matter of holding onto their relationship with place. Power and place are embedded.

Reid carefully walks the reader through the "shifting balance of power" in Native marine and terrestrial spaces and calls out a very basic but subtly perpetuated myth that Indian "savagery" explained violent attacks on settlers. He sets the record straight 
that the Makahs were "exercising sovereignty over indigenous spaces." Following the Native and nonNative competition for resources, the Makahs both discouraged settlement around Cape Flattery while taking advantage of the trade opportunities settlers presented. There is a constant negotiation between settlers and Natives as territorial presence, trade arrangements, and mutual threats of violence are navigated.

Finally, and most importantly, Reid debunks the myth of an all-powerful colonial presence and reveals the complex interdependent relationship that existed in the cača-di borderlands, which is a 500-mile stretch of marine space significant to native sociocultural networks. Settler colonists were dependent on Natives for their indigenous knowledge that supported their vitality in the region. Reid gives great credence to the efficacy of indigenous knowledge. For example, knowledge of weather, seasons, biota, and ocean currents, perfected over generations spent in the same place, guided the Makahs as they honed appropriate technologies and techniques in support of their livelihood. Newcomers relied on Natives for food and fuel (whale oil) as well as their highly developed skills and tools in the marine environment. Knowledge is power for the Makahs in that settler colonial dependency on native know-how gave the Makahs bargaining power in the treaty process and lesser transactions of power. Reid acknowledges what few do: the essential reliance settler colonists had on native people in their colonial endeavors. He goes so far as to say that the colonial endeavor was dependent on native participation. By demonstrating how the People of the Cape combined customary practices with new opportunities and technologies to succeed on their own terms in the settler-colonial world, Reid turns "dependency theory" on its head.

Nuancing his discussion of indigenous knowledge, Reid delves into the Makah worldview, which "equated spirituality with responsible stewardship" (148). The spiritual beliefs and practices, which guided Makah life and whaling, were starkly different from those of the colonial system. From the Makah perspective of a "sacred ecology," they saw themselves as relatives of the non-human actors in their environment. The Makah recognized a "responsibility to maintain balanced relationship with the non-human people of the region" (153). From the earliest interactions between Natives and non-Natives throughout the treaty period and Native recovery of whaling practices in the 1990 s, misunderstandings of cultural differences such as the native kincentric viewpoint and the gift economy that balanced power through acts of reciprocity, lead to fundamental breakdowns in cross-cultural exchange.

Examining the relationship of the Makah to their marine and terrestrial spaces, borderlands dynamics, pressure on resources including the Makah food supply and trade goods, spiritual beliefs and customary practices, Reid holds on tightly to the thread of resistance and the changing tide of Native agency in the colonial context. He demonstrates how by taking advantage of trade opportunities and participating in the extraction industry, the Makah integrated colonial practices into their own customary lifeways as a strategy of survival in the context of a fierce competition for resources. Reid emphasizes that the Makah, through the persistence of their leadership in negotiation with the US government, preserved their relationship with the sea, and engaged the settlercolonial world on their own terms. The power that they retained in this process allowed the Makah to hold "enough power" to complicate imperial processes and hang on to their own destiny. Reid's nuanced view stands as a shining example for scholars writing indigenous-environmental history, one that dispels familiar myths perpetuated by both historical sources and previous scholarship. 